\title{
Parasitism of Trichogramma Pretiosum in Eggs of Corcyra Cephalonica on the Age of the Parasitoid and the Density of the Host
}

Gabriel Monteiro ( $\sim$ gabrielmonteiro7777@hotmail.com )

São Paulo State University

Sofía Jorge

São Paulo State University

Amanda Fernandes Lemes

São Paulo State University

Nathália dos Santos

Universidade de São Paulo

Dagmara Ramalho

São Paulo State University

Sergio de Bortoli

São Paulo State University

\section{Research Article}

Keywords: Egg parasitoids, functional response, laboratory rearing, rice moth

Posted Date: August 11th, 2021

DOl: https://doi.org/10.21203/rs.3.rs-785544/v1

License: (9) (i) This work is licensed under a Creative Commons Attribution 4.0 International License. Read Full License 


\section{Abstract}

Several biological control programs use Trichogramma pretiosum Riley (Hymenoptera:

Trichogrammatidae). The parasitism capacity and the functional response of T. pretiosum parasitizing eggs of Corcyra cephalonica (Stainton) (Lepidoptera: Pyralidae) were studied. To determine the parasitism capacity, females of the parasitoid were individualized, being offered to each female eggs from the host. Daily observations determined the number of parasitized eggs per female, accumulated percentage of parasitism, female longevity and percentage of parasitoid emergence. To establish the functional response, T. pretiosum females were individualized and offered $C$. cephalonica eggs. Number of parasitized eggs and percentage of adults' emergence were evaluated, being calculated handling time (Th) and attack rate (a). On the first day of the parasitoid's life there was parasitism in more than $80 \%$ of the host eggs, similar to the percentage of adult emergence throughout the life cycle, and the daily percentage of parasitism. The percentages of eggs of $C$. cephalonica parasitized were statistically different, with the quadratic model better describing the parasitoid-host relationship, with a positive value of 0.00594 , since with the increase in the availability of eggs of $C$. cephalonica, parasitism was increased. The attack rate was approximately 0.00158 , while the handling time of the host eggs was $0.6884 \mathrm{~h}$.

\section{Introduction}

In the current global agricultural scenario, several management tactics are employed, either alone or in association, with the objective of combating pest insects capable of producing economic damages in different crops. Among the control tactics, the biological one has the ability to significantly reduce the impact of chemicals on the environment (Parra et al. 2015), and the use of parasitoids as control agents can be highly effective, particularly due to their high host specificity (Nasrin et al. 2016).

The genus Trichogramma spp., among the parasitoids, is one of the most studied due to its wide geographical distribution and ease of rearing in the laboratory (Nasrin et al. 2016). More than 210 species of Trichogramma occur in the world, of which 28 are cited in South America, with Brazil having the largest number of records, with 28 species (Pinto 2006). The females of these insects parasitize especially pest lepidopteran eggs, preventing their hosts from passing to larval stage (Haji et al. 1995).

Trichogramma pretiosum Riley (Hymenoptera: Trichogrammatidae), a species of Mexican and American origin, is the most distributed worldwide, with the occurrence of its parasitism in 18 hots of approximately 13 crops of economic importance (Zucchi and Monteiro 1997). It is an idiobionte species, since it parasitizes eggs of different insect orders, including Coleoptera, Diptera, Hemiptera, Hymenoptera, Lepidoptera, Neuroptera and Thysanoptera, preventing their hosts from reaching the larval stage (Monnerat et al. 2007; Carvalho et al. 2014; Amaro et al. 2015).

For the massal rearing of Trichogramma spp. alternative or replacement hosts have been used, that is, hosts that are not parasitized in natural conditions, the main objective being to reduce costs and increase 
efficiency, but with the guarantee of adequate development (Parra 1997), as has happened with the lepidopterans Anagasta kuehniella (Zeller) (Pyralidae), Sitotroga cerealella Oliver (Gelechiidae) and Corcyra cephalonica (Stainton) (Pyralidae) (Zagatti et al. 1987; Chandrawanshi et al. 2018).

Various characteristics of host eggs, such as size, chorion thickness, nutritional value and age can affect the development and quality of the parasitoids produced, directly influencing the percentage of parasitism, the sex ratio and the number of individuals generated per egg host, relations that may vary according to the species (Hoffmann et al. 2001; Roriz et al. 2006; Rukmowati-Brotodjojo and Walter 2006).

Corcyra cephalonica has been shown to be easy to rear in the laboratory, providing a large quantity of eggs, which favors the numerical success for the multiplication of parasitoids in massal laboratory rearing, with low production cost, in whose diet only two ingredients are used, wheat germ and yeast (De Bortoli et al. 2012).

For the success of a biofactory in the massal rearing of insects aiming at the applied biological control, it is essential to understand the parasitoid $\mathrm{x}$ host relationship, particularly regarding its biological, ecological, behavioral aspects and, especially, the qualitative nutritional aspects (Pastori et al. 2010). Some authors such as Bernardi, Haddad and Parra (2000) and Chaudhuri and Senapati (2017) have already demonstrated that $C$. cephalonica is a potential host for the rearing of $T$. pretiosum.

However, studies on the parasitism capacity for the genus Trichogramma are necessary, in order to measure the rate of predation or parasitism as a function of host density, contributing to the understanding of the process of predation or parasitism, allowing to infer comparisons and estimates that indicate the potential of success of the studied agent, both in massal rearing, as in applied biological control (Hassell 1978). In this sense, the present study evaluated the effect of the parasitoid's age on its reproductive capacity, the availability of host eggs on the potential of parasitism and the viability of $T$. pretiosum, an important contribution to the use of the alternative host $C$. cephalonica in biofabrics of massal rearing of the parasitoid, as well as, in the decision making of its release in the field to control pest insects.

\section{Results}

\section{Parasitism capacity}

The percentages of $C$. cephalonica eggs parasitized by $T$. pretiosum females on the different days of their longevity (1 to 15 days) showed significant differences, with emphasis on the first day of life with more than $80 \%$ of the parasitized eggs. Between the 2 nd and the 5th and on the 10th, 11th, 12 th and 13th day of life of the females the percentages of parasitized eggs ranged from 33.3 to $53.2 \%$, while in the others they were always below $30 \%$ (Table 1 ). 
Table 1

Percentage of Corcyra cephalonica eggs parasitized by Trichogramma pretiosum during 15 days of female longevity.

\begin{tabular}{|ll|}
\hline Female age & Means \pm Standard error \\
\hline 01 day & $85.4 \pm 4.77 \mathrm{a}^{1}$ \\
\hline 02 days & $53.2 \pm 4.44 \mathrm{~b}$ \\
\hline 03 days & $39.4 \pm 4.93 \mathrm{bcd}$ \\
\hline 04 days & $44.0 \pm 3.40 \mathrm{bc}$ \\
\hline 05 days & $33.4 \pm 3.33 \mathrm{bcd}$ \\
\hline 06 days & $27.1 \pm 2.28 \mathrm{~cd}$ \\
\hline 07 days & $23.1 \pm 2.42 \mathrm{~cd}$ \\
\hline 08 days & $24.3 \pm 2.45 \mathrm{~cd}$ \\
\hline 09 days & $27.2 \pm 2.42 \mathrm{~cd}$ \\
\hline 10 days & $38.4 \pm 6.86 \mathrm{bcd}$ \\
\hline 11 days & $37.8 \pm 8.82 \mathrm{bcd}$ \\
\hline 12 days & $33.3 \pm 8.56 \mathrm{bcd}$ \\
\hline 13 days & $36.2 \pm 8.28 \mathrm{bcd}$ \\
\hline 14 days & $16.6 \pm 3.87 \mathrm{~d}$ \\
\hline 15 days & $29.3 \pm 6.40 \mathrm{~cd}$ \\
\hline 1 Means \pm standard error followed by the same letter in the column do not differ by Student Newman \\
\hline Kells $(0.05 \%),(F=1.43 ;$ df $=14 ; 0<001)$. \\
\hline
\end{tabular}

The percentages of emergence of adults of $T$. pretiosum from the eggs of $C$. cephalonica parasitized by females at different ages were similar in practically the entire period of life (ranging from 95.8 to $69.1 \%$ ), differing only in the 5 th and 7 th day of female longevity (64.0 and 53.6\%, respectively) (Table 2 ). 
Table 2

Percentage of emergence of Trichogramma pretiosum from eggs of Corcyra cephalonica parasitized during 15 days of female longevity.

\begin{tabular}{|l|l|}
\hline Female age & Means \pm Standard error \\
\hline 01 day & $95.8 \pm 3.32 \mathrm{a}^{1}$ \\
\hline 02 days & $87.8 \pm 5.48 \mathrm{ab}$ \\
\hline 03 days & $79.5 \pm 8.13 \mathrm{ab}$ \\
\hline 04 days & $94.3 \pm 1.44^{\mathrm{a}}$ \\
\hline 05 days & $64.0 \pm 6.19 \mathrm{bc}$ \\
\hline 06 days & $89.1 \pm 5.69 \mathrm{ab}$ \\
\hline 07 days & $53.6 \pm 7.41 \mathrm{c}$ \\
\hline 08 days & $85.8 \pm 5.78 \mathrm{ab}$ \\
\hline 09 days & $97.7 \pm 1.72^{\mathrm{a}}$ \\
\hline 10 days & $97.3 \pm 1.45^{\mathrm{a}}$ \\
\hline 11 days & $83.0 \pm 4.96 \mathrm{ab}$ \\
\hline 12 days & $92.0 \pm 5.81^{\mathrm{a}}$ \\
\hline 13 days & $89.5 \pm 2.80 \mathrm{ab}$ \\
\hline 14 days & $76.1 \pm 9.73 \mathrm{ab}$ \\
\hline 15 days & $69.1 \pm 11.10 \mathrm{abc}$ \\
\hline $\begin{array}{l}\text { Means } \pm \text { standard error followed by the same letter in the column do not differ by Student Newman } \\
\text { Kells }(0.05 \%),(F=2.78 ; d f=14 ; p<0.001) .\end{array}$ \\
\hline
\end{tabular}

The daily percentage of parasitism practically uniform during the 15 days of longevity of the females, with emphasis on the first two days, with values close to $50 \%$ (Fig. 1).

Functional response

Among the models used to determine the functional response, the quadratic described the best arrangement, with a positive value of 0.00594 (Table 3). With the increase in the availability (density) of C. cephalonica eggs, there was also an increase in parasitism by T. pretiosum (Fig. 2). The attack rate of the parasitoid was approximately 0.00158 eggs $^{-1}$, while the handling time was $0.6884 \mathrm{~h}$ (Table 4). 
Table 3

Parameters estimated by logistic regression between the proportion of Corcyra cephalonica eggs parasitized by Trichogramma pretiosum.

\begin{tabular}{|lllll|}
\hline Parameters & Values $\pm \mathbf{S E}^{*}$ & $\mathbf{D F}^{* *}$ & $\mathbf{\chi}^{2}$ & $\mathbf{P}$ \\
\hline Intercept & $-0.3239 \pm 0.2459$ & 1 & 1.73 & 0.1878 \\
\hline Linear & $-0.1106 \pm 0.0388$ & 1 & 8.12 & 0.0044 \\
\hline Quadratic & $0.00594 \pm 0.00149$ & 1 & 15.84 & $<0.0001$ \\
\hline Cubic & $-0.00007 \pm 0.000015$ & 1 & 19.76 & $<0.0001$ \\
\hline *Standard error & & & \\
${ }^{* *}$ Degree of freedom & & & \\
\hline
\end{tabular}

Table 4

Attack rate and handling time of Corcyra cephalonica eggs by Trichogramma pretiosum, in different densities and during 24 $\mathrm{h}$ of exposure.

\begin{tabular}{|lll|}
\hline Attack rate $\left(a^{\prime}\right)$ & Handling time $(T h)$ & $a^{\prime} / T h$ \\
\hline $0.00158 \pm 0.000310$ & $0.6884 \pm 0.0670$ & 34.86 \\
$(0.000966-0.8210)^{1}$ & $(0.5588-0.8210)$ & $(42.9-29.2)$ \\
\hline${ }^{1}$ Means $\pm 95 \%$ confidence interval. & \\
\hline
\end{tabular}

\section{Discussion}

The females of $T$. pretiosum responded to the availability of host eggs during their longevity, maintaining an average daily parasitism with the exception of the first $24 \mathrm{~h}$ which was higher, and without significant losses to the total fecundity of the females. That way, females of $T$. pretiosum were able to perform postures from the first day to the last day of life (15th day), differently from what was observed in the works of Pastori et al. (2007), dos Santos (2007) and Carvalho et al. (2014) for T. pretiosum and other species of the genus, where daily parasitism was higher in the first $24 \mathrm{~h}$, decreasing after this period. According to Queiroz et al. (2020), for the parasitoid with one to five days of longevity, the efficiency of parasitism remained the same in eggs of Anticarsia gemmatalis (Hübner) (Lepidoptera: Noctuidae). Another point to be highlighted is the temperature at which the bioassay was carried out, $25 \pm 2^{\circ} \mathrm{C}$, which may have disadvantaged the percentage of parasitism. Kumari et al. (2020) reported that the percentage of parasitism of Trichogramma chilonis Ishii in C. cephalonica, at this same temperature, was $58.67 \%$, while Oliveira et al. (2017) reported that at $28^{\circ} \mathrm{C}, 100 \%$ of the parasitized eggs of Neoleucinodes elegantalis (Gueneé) (Lepidoptera: Crambidae) resulted in the emergence of adults from the parasitoid. 
Parveen and Sultan (2012) also found the maximum parasitism achieved (84.3\%) in eggs of $C$. cephalonica at a temperature of $28{ }^{\circ} \mathrm{C}$. In addition, the species of lineage of the parasitoid and host used can influence the parasitism capacity (Hassan and Guo 1991; Hansen and Jensen 2002; Pratissoli et al. 2004).

With 14 days old females there was instability in the value of the percentage of parasitism. Laurentis et al. (2019) describe those irregularities in parasitism rates are common, as these insects, when reared in the laboratory, tend to modify this behavior and develop adaptations throughout the entire life cycle, affecting the efficiency of parasitism. The accumulated percentage of parasitism steadily increased until the end of the assessment, resulting in an increase in that rate until the end of the experiment (Subandi et al. 2017). However, it is important to consider that T. pretiosum has its population reduced throughout its longevity.

As for the percentage of $T$. pretiosum emergence, only with females of five, seven and 15 days of longevity was not found an ideal emergency for Trichogramma, which is above $85 \%$, according to Navarro (1998). Viability is directly related to host characteristics, such as egg quantity and nutritional quality of them. Thereby, it was found that $C$. cephalonica eggs are suitable for the development of $T$. pretiosum. In this sense, Pratissoli and Oliveira (1999) and Gonçalves et al. (2003), evaluating the viability of $T$. pretiosum in eggs of Helicoverpa zea (Boddie) (Lepidoptera: Noctuidae) and S. cerealella, obtained values above $91 \%$ and $89 \%$, respectively, corroborating with the percentages found in this work. According to the International Organization for Biological Control (IOBC), for parasitoids of the genus Trichogramma the average indexes recommended as a quality standard are: parasitism $\geq 25$ eggs/female in 48 hours; emergence $\geq 80 \%$; sex ratio $\geq 0.5$ and longevity $\geq 7$ days (Van Lenteren 1994). In this work, the first day of parasitism with 48 hours was considered, since in the first 24 hours the parasitoids were mated, this suggesting that $T$. pretiosum in the host $C$. cephalonica fits the IOBC quality indexes, even though the sex ratio was not observed.

Among the tested statistical models, the quadratic one described the best arrangement. This model has also been observed in previous research with T. pretiosum in Tuta absoluta (Meyrick) (Lepidoptera: Gelechiidae) eggs in tomato in natural field conditions (Pratissoli et al., 2005), and with Trichogramma atopovirilia Oatman and Platner (Hymenoptera: Trichogrammatidae) in $\mathrm{H}$. zea eggs at $25^{\circ} \mathrm{C}$ (Paron et al. 1998). Cabello and Vargas (1985) also obtained the same model working with Trichogramma cordubensis Vargas and Cabello (Hymenoptera: Trichogrammatidae) on eggs of Ephestia kuehniella Zeller (Lepidoptera: Pyralidae) at $20^{\circ} \mathrm{C}$, inferring that the percentage of parasitized eggs stabilized with the increase of parasitoid density from ten females. This fact was explained by the numerical superiority of females able to parasitism, because the lower the density of females, the greater was the number of parasitized eggs.

The type II functional response, considered quadratic, shows that, according to the increase in the availability of $C$. cephalonica eggs, there is an increase in parasitism by $T$. pretiosum. The limit reached in this work is approximately 25 parasitized eggs, even though there are more than 60 available eggs. This 
behavior is also mentioned by Price (1975) as Holling type II functional response, as parasitism increases at a decreasing rate with the increase in the number of hosts, a behavior that is commonly observed in parasitoids and insect predators (Holling 1961). Milanez et al. (2018) also recorded the same type of functional response, with the same parasitoid, in eggs of Trichoplusia ni (Hübner) (Lepidoptera:

Noctuidae), concluding that the decrease in oviposition due to the limitation of parasitoid eggs is due to its endocrine oviposition control system, even if eggs are available, not due to the absence of oogenesis, but due to the regulation of neurohormones (Reznik et al. 2003).

The attack rate of T. pretiosum in C. cephalonica eggs was lower than that mentioned by Godfray (1994), with a variation between 0.002 and $0.030 . \mathrm{h}^{-1}$, generally for parasitoids. Changes in the parameters of the functional response are frequent for parasitoids and predator, according to factors such as host and environmental conditions, which particularly affect the foraging capacity and, consequently, the foraging rate (Mackauer 1983). The lower attack rate found in this work demonstrates that the parasitoid exploits a smaller area to find the host, and that although there is a reduction in the area explored, the expected average number of parasitized eggs is reached.

Trichogramma pretiosum showed good biological performance in eggs of $C$. cephalonica, with high values for the potential for parasitism and percentage of emergence in the first 48 hours of life.

Trichogramma pretiosum has reproductive capacity throughout its longevity.

High density of available host eggs induces T. pretiosum to parasitize a greater number of eggs (between 25 to 30 eggs).

\section{Methods}

The bioassays, as well as the rearing of $T$. pretiosum and $C$. cephalonica, were conducted in the Laboratório de Biologia e Criação de Insetos (LBCl) of the Departamento de Ciências da Produção Agrícola (Fitossanidade), Faculdade de Ciências Agrárias e Veterinárias, UNESP, Jaboticabal, SP, in controlled conditions of temperature $\left(25 \pm 2^{\circ} \mathrm{C}\right)$, relative humidity $(70 \pm 10 \%)$ and daily photoperiod $(12 \mathrm{~h}$ light and $12 \mathrm{~h}$ dark).

Rearing of the host Corcyra cephalonica

The eggs of $C$. cephalonica were obtained from the $\mathrm{LBCl}$ stock rearing, and a parallel rearing was conducted to supply the eggs needed for bioassays using a diet consisting of wheat germ (94\%), sterilized at $150^{\circ} \mathrm{C}$ for two hours, and beer yest (6\%) (Bernardi et al. 2000). The diet was arranged in 47.0 $\mathrm{cm} \times 29.5 \mathrm{~cm} \times 10.5 \mathrm{~cm}$ plastic containers, distributed in four parallel grooves and in direction of the length of the container $0.15 \mathrm{~g}$ of eggs, with subsequent closure with plastic lids containing central holes covered with voile-type fabric, measuring $6.0 \mathrm{~cm} \times 8.0 \mathrm{~cm}$. The newly emerged adults were collected daily using a vacuum cleaner adapted with a capture chamber built with a PET bottle and PVC pipe. The collected adults were transferred to cylindrical glass containers $(11.0 \mathrm{~cm}$ in diameter $x 17.0 \mathrm{~cm}$ in height) 
containing a piece of sombrite type-screen folded in "Z" (substrate for oviposition), the container being closed with the same type of screen. The eggs were collected daily by inverting the adults' container on a white plastic tray, tapping the bottom of the container with the palm of the hand, so that the eggs adhered to the laying substrate would detach and fall into the tray. The eggs were sieved to remove impurities, part of which was used to maintain the rearing itself and another part to carry out the bioassays. The eggs produced and momentarily not used were stored in a refrigerator (temperature close to $10^{\circ} \mathrm{C}$ ) (Jacob and Cox 1977).

Rearing of the parasitoid Trichogramma pretiosum

The parasitoids used in the bioassays came from the LBCl stock rearing, and their maintenance was carried out according to the methodology described by Parra (1997). Before making the cards with $C$. cephalonica eggs, they underwent a non-viability process with exposure to the germicidal lamp for 45 minutes. Then, the unviable eggs adhered to cards of sky-blue paperboard $(3.5 \mathrm{~cm} \times 1.5 \mathrm{~cm})$, with fixation on double-sided adhesive tape $(2.5 \mathrm{~cm} \times 1.2 \mathrm{~cm})$, were exposed to parasitism, with the cards positioned inside flat-bottom test tubes $(2.0 \mathrm{~cm}$ in diameter $\times 8.0 \mathrm{~cm}$ in high), containing adults of $T$. pretiosum newly emerged. On the surface of the inner side of the tube, a droplet of honey was added to feed the parasitoids. The card was replaced every 24 hours, for five days, and those with parasitized eggs were transferred to another similar tube, with the tubes always being sealed with PVC film, with the emergence of adult insects in these tubes.

Assessment of parasitism capacity

Females of T. pretiosum were individualized in 30 Duran glass tubes $(3.0 \mathrm{~cm}$ in length $\times 0.90 \mathrm{~mm}$ in diameter) and sealed with PVC film. For each female, 30 eggs of $C$. cephalonica were offered, aged between 0 and $24 \mathrm{~h}$, adhered to cards of sky-blue paperboard. The cards were replaced every 24 hours for the entire longevity of the females, being identified and maintained in the same conditions. Daily it was determined: the number of parasitized eggs, accumulated percentage of parasitism, total number of parasitized eggs per female, female longevity and percentage of emergence of adults. The design used was completely randomized design (CRD), and the data analysis was conducted with the SAS ${ }^{8}$ Software. For the analysis, the data were submitted to Bartlett's tests to verify homoscedasticity (PROC GLM), and Cramer von Mises test for normality (PROC UNIVARIATE). As the data did not present such requirements, the transformation at $x+0.5$ was used for the Analysis of Variance (PROC ANOVA). The means, when significant, were compared using the Student Newman Kells test $(p>0.05)$.

Functional response of Trichogramma pretiosum with Corcyra cephalonica eggs

Females of $T$. pretiosum were individualized in 140 flat-bottom test tubes $(2.0 \mathrm{~cm}$ in diameter $\times 8.0 \mathrm{~cm}$ in high) and sealed with PVC film. For each female, eggs were offered between 0 and $24 \mathrm{~h}$ of laying and in densities of $1,2,4,8,16,32$ and 64 , adhered to cards of sky-blue paperboard. The cards were removed after $24 \mathrm{~h}$ of exposure to parasitism, with 20 repetitions per egg density. The assessments were carried out after 10 days, determining the number parasitized eggs and the percentage of emergence of adults. 
Subsequently, the random equation of functional response proposed by Rogers (1972) was used, calculating the handling time (Th) and attack rate (a), with the construction of the functional response equation. The parameters were determined by the graphical linearization of the values of the number of parasitized eggs ( $x$-axis) and the natural logarithm ( $L n)$ of the proportion of remaining eggs ( $y$-axis). Using the slope of the straight line divided by $24 \mathrm{~h}$, the attack rate (a) (eggs/h) was obtained in hours. Dividing this value by the slope of the line gave the handling time (Th), also measured in hours. The estimated parameters of attack rate ( $h-1)$ and handling time $(h)$ were compared between densities using the confidence interval $(\mathrm{Cl})$ at $95 \%$ probability, differing the means in which the $\mathrm{Cl}$ did not overlap.

The predation data were submitted to Student's test to determine the significance among treatments, using the SAS ${ }^{\circledR}$ Software, with the functional response determined by means of the logistic regression of the proportion of eggs consumed according to the original densities, using different models, using PROC CATMOD, with the random parasitism equation adjusted to the results by PROC NLIN (Juliano 2001).

\section{Declarations}

\section{ACKNOWLEDGMENTS}

This study was financed in part by the Coordination for the Improvement of Higher Level Personnel (CAPES) - Finance Code 001 and by the National Council for Scientific and Technological Development (CNPq). The authors also thank Leonardo Henrique Lucas Costa Mello for the artistic layout of the figures.

\section{AUTHOR CONTRIBUTIONS}

G.G.M., S.J.J., A.A.F.L. and N.A.S. wrote the main manuscript text and prepared all figures and tables. All authors reviewed the manuscript.

\section{ADDITIONAL INFORMATION}

The authors declare no competing interests.

\section{References}

1. Amaro, J. T., Bueno, A. F., Pomari-Fernandes, A. F., Neves \& P. M. O. J. Selectivity of Organic Products to Trichogramma pretiosum Riley (Hymenoptera: Trichogrammatidae). Neotrop. 44, 489-997 (2015).

2. Bernardi, E. B., Haddad, M. L. \& Parra, J. R. P. Comparison of artificial diets for rearing Corcyra cephalonica (Stainton, 1865) (Lep., Pyralidae) for Trichogramma mass production. Braz. J. Biol. 60, 45-52 (2000).

3. Cabello, G. T. \& Vargas, P. P. Temperature as a fator influencing the form of reproduction of Trichogramma cordubensis Vargas \& Cabello (Hym., Trichogrammatidae). Zeitschrift. 100, 434-441 (1985). 
4. Carvalho J. R. et al. Parasitism capacity of Trichogramma pretiosum on eggs of Trichoplusia ni at different temperatures. Acta Sci. Agron. 36, 417-424 (2014).

5. Chandrawanshi, P., Aherkar, S. K., Thakare, V. S. \& Shendage, S. A. Effect of magnetic field and different diets on the biological parameters of rice moth, Corcyra cephalonica (Stainton). J. Entomol. Zool. Stud. 6, 74-76 (2018).

6. Chaudhuri, N. \& Senapati, S. K. Development and reproductive performance of rice moth Corcyra cephalonica Stainton (Lepidoptera: Pyralidae) in different rearing media. J. Saudi Soc. Agric. Sci. 16, 337-343 (2017).

7. De Bortoli, A. S. et al. Produção de insetos: da base a biofábrica in Tópicos em Entomologia Agrícola (ed. Busoli, A. C. et al.) 323-342 (Multipress, Jaboticabal, Brasil, 2012).

8. Godfray, H. C. J. Parasitoids in Behavioral and Evolutionary Ecology (ed. Princeton University, New Jersey, USA) (1994).

9. Gonçalves, J. R., Holtz, A. M., Pratissoli, D. \& Guedes, R. N. C. Avaliação da qualidade de Trichogramma pretiosum (Hymenoptera: Trichogrammatidae) em ovos de Sitotroga cerealella (Lepidoptera: Gelechiidae). Acta Sci. Agron. 25, 485-489 (2003).

10. Haji, F. N. P. et al. Manejo integrado de Scrobipalpuloides absoluta (Povolny) (Lepidoptera: Gelechiidae) no Submédio São Francisco. An. Soc. Entomol. Bra. 24, 587-591 (1995).

11. Hansen, L. S. \& Jensen, K. M. Effect of temperature on parasitism and host-feeding of Trichogramma turkestanica (Hymenoptera: Trichogrammatidae) on Ephestia kuehniella (Lepidoptera: Pyralidae). J. Econ. Entomol. 95, 50-56 (2002).

12. Hassan, S. A. \& Guo, M. F. Selection of effective strains of egg parasites of the genus Trichogramma (Hym., Trichogrammatidae) to control the European corn borer Ostrinia nubilalis Hb. (Lep., Pyralidae). J. Appl. Entomol. 111, 335-341 (1991).

13. Hassell, M. P. The dynamics of arthropod predator-prey systems (ed. Princeton University, New Jersey, USA) (1978).

14. Hoffmann, M. P. et al. Performance of Trichogramma ostriniae (Hymenoptera: Trichogrammatidae) reared on factitious hosts, including the target host, Ostrinia nubilalis (Lepidoptera: Crambidae). Biol. Control. 21, 1-10 (2001).

15. Holling, C. S. Principies of insect predation. Ann. Rev. Entomol. 6, 163-182 (1961).

16. Jacob, T. A. \& Cox, P. D. The influence of temperature and humidity on the life-cycle of Ephestia kuehniella Zeller (Lepidoptera: Pyralidae). J. Stored Prod. Res. 13, 107-118 (1977).

17. Juliano, S. A. Non-linear curve fitting: predation and functional response curves in Design and analysis of ecological experiments (ed. Scheiner, S. M. \& Gurevitch, J.) 178-196 (Oxford University, UK, 2001).

18. Kumari, R., Singh, N. N., Raju, S. V. S. \& Singh, P. S. Effect of different temperatures on Trichogramma chilonis (Hymenoptera: Trichogrammatidae) parasitizing the eggs of Corcyra cephalonica and Helicoverpa armigera. J. Entomol. and Zoo. Stud. 8, 419-423 (2020). 
19. Laurentis, V. L. et al. Performance of Trichogramma pretiosum Riley (Hymenoptera:

Trichogrammatidae) on eggs of Helicoverpa armigera (Hubner) (Lepidoptera: Noctuidae). Sci. Report. 9, 1156 (2019).

20. Mackauer, M. Quantitative assessment of Aphidius smithi (Hymenoptera: Aphidiidae): fecundity, intrinsic rate of increase, and functional response. Canad. Entomol. 115, 399-415 (1983).

21. Milanez, A. M., Carvalho, J. R., Lima, V. L. S. \& Pratissoli, D. Functional response of Trichogramma pretiosum on Trichoplusia ni eggs at different temperatures and eggs densities. Pesq. Agropec. Bras. 53, 641-645 (2018).

22. Monnerat, R. S. et al. Screening of brazilian Bacillus thuringiensis isolates active against Spodoptera frugiperda, Plutella xylostella and Anticarsia gemmatalis. Biol. Control. 41, 291-295 (2007).

23. Nasrin, M., Alam, M. Z., Alam, S. N., Miah, M. R. U. \& Hossain, M. M. Effect Of Various Cereals On The Development Of Corcyra cephalonica (Stainton) And Its Egg Parasitoid Trichogramma chilonis (Ishii). Bangladesh J. Agr. Res. 41, 83-94 (2016).

24. Navarro, M. A. Trichogramma spp. producción, uso y manejo en Colombia. (ed. CO-BAC) (Bogotá, Colombia, 1998).

25. Oliveira, C. M. et al. Biological parameters and termal requirements of Trichogramma pretiosum for the management of tomato fruit borer (Lepidoptera: Crambidae) in tomatões. J. Crop Prot. 99, 39-44 (2017).

26. Paron, M. J. F. O., Ciociola, A. I. \& Cruz, I. Resposta de Trichogramma atopovirilia Oatman \& Platner (Hymenoptera: Trichogrammatidae) a Diferentes Densidades de Ovos do Hospedeiro Natural, Helicoverpa zea (Boddie) (Lepidoptera: Noctuidae). An. Soc. Entomol. Bra. 27, 427-433 (1998).

27. Parra, J. R. P. Técnicas de criação de Anagasta kuehniella, hospedeiro alternativo para produção de Trichogramma in Trichogramma e o controle aplicado (ed. Parra, J. R. P. \& Zucchi, R. A.) 121-150 (FEALQ, Piracicaba, Brasil, 1997).

28. Parra, J. R. P., Zucchi, R. A., Coelho, Jr. A., Geremias, L. D. \& Cônsoli, F. L. Trichogramma as a tool for IPM in Brazil in Augmentative Biological Control using Trichogramma spp.: Current Status and Perspectives (ed. Vinson, B., Greenberg, S. M., Liu, T., Rao, A. \& Volosciuk, L. F.) 472-496 (Northwest A \& F University Press, China, 2015).

29. Parveen, F. \& Sultan, R. Effects of the host and parasitoid densities on the quality production of Trichogramma chilonis on Lepidopterous (Sitotroga cerealella and Corcyra cephalonica) eggs. Arthropods. 1, 63-72 (2012).

30. Pastori, P. L., Monteiro, L. B., Botton, M. \& Pratissoli, D. Parasitism capacity of Trichogramma pretiosum Riley (Hymenoptera: Trichogrammatidae) reared under different temperatures on Bonagota salubricola (Meyrick) (Lepidoptera: Tortricidae) eggs. Neotrop. 36, 926-931 (2007).

31. Pastori, P. L., Monteiro, L. B., Botton, M. \& Pratissoli, D. Efeito da idade do parasitoide e do hospedeiro na reprodução de Trichogramma pretiosum Riley (Hymenoptera: Trichogrammatidae) em ovos de Bonagota salubricola (Meyrick) (Lepidoptera: Tortricidae). Arq. Inst. Biol. 77, 349-353 (2010). 
32. Pinto, J. D. A review of the New World genera of Trichogrammatidae (Hymenoptera). J. Hymen. Res. 15, 38-163 (2006).

33. Pratissoli, D., Pereira, F. F., Barros, R., Parra, J. R. P. \& Pereira, C. L. T. Parasitismo de Trichogramma pretiosum em ovos da traça-das-crucíferas sob diferentes temperaturas. Hort. Bra. 22, 754-757 (2004).

34. Pratissoli, D. \& Oliveira, H. N. Influência da idade dos ovos de Helicoverpa zea (Boddie) no parasitismo de Trichogramma pretiosum Riley. Pesq. Agrop. Bra. 34, 891-896 (1999).

35. Pratissoli, D., Thuler, R. T., Andrade, G. S., Zanotti, L. C. M. \& Silva, A. F. Estimativa de Trichogramma pretiosum para o controle de Tuta absoluta em tomateiro estaqueado. Pesq. Agrop. Bra. 40, 715-718 (2005)

36. Price, P. W. Insect ecology (ed. A Wiley-Interscience Publication, New York, USA) (1975)

37. Queiroz, A. P., Costa, C. O., Favetti, B. M., Silva, G. V. \& Bueno, A. F. Effects of parasitoid and host age on the parasitism of Trichogramma pretiosum on eggs of Anticarsia gemmatalis. Rev. Bra. Entomol. 62, 1-5 (2020).

38. Reznik, S. Y., Umarova, T. Y. \& Voinovich, N. D. Egg retention in Trichogramma (Hymenoptera: Chalcidoidea: Trichogrammatidae): Learning or diapause? Acta. Soc. Zoo. Bohemicaes. 67, 25-33 (2003).

39. Rogers, D. Random search and insect population models. J. Animal Ecol. 41, 369-383 (1972).

40. Roriz, V., Oliveira, L. \& Garcia, P. Host suitability and preference studies of Trichogramma cordubensis (Hymenoptera: Trichogrammatidae). Biol. Control. 36, 331-336 (2006).

41. Rukmowati-Brotodjojo, R. R. \& Walter, G. H. Oviposition and reproductive performance of a generalist parasitoid (Trichogramma pretiosum) exposed to host species that differ in their physical characteristics. Biol. Control. 39, 300-312 (2006).

42. Subandi, M., Setiati, Y. \& Mutmainah, N. H. Suitability of Corcyra cephalonica eggs parasitized with Trichogramma japonicum as intermediate host against sugarcane borer Chilo auricilius. Bulgarian J. Agri. Sci. 23, 779-786 (2017).

43. Van Lenteren, J. C. Designing and implementing quality control of beneficial insects: towards more reliable biological pest control. Newsletter. Biol. Control. Greenhouses. 14, 3-24 (1994).

44. Zagatti, P. et al. Sex pheromones of rice moth, Corcyra cephalonica Stainton. J. Chemical. Ecol. 13, 1561-1573 (1987).

45. Zucchi, R. A. \& Monteiro, R. C. 0 gênero Trichogramma na América do Sul in Trichogramma e o controle biológico aplicado (ed. Parra, J. R. P. \& Zucchi, R. A.) 41-66 (FEALQ, Piracicaba, Brasil, 1997).

\section{Figures}




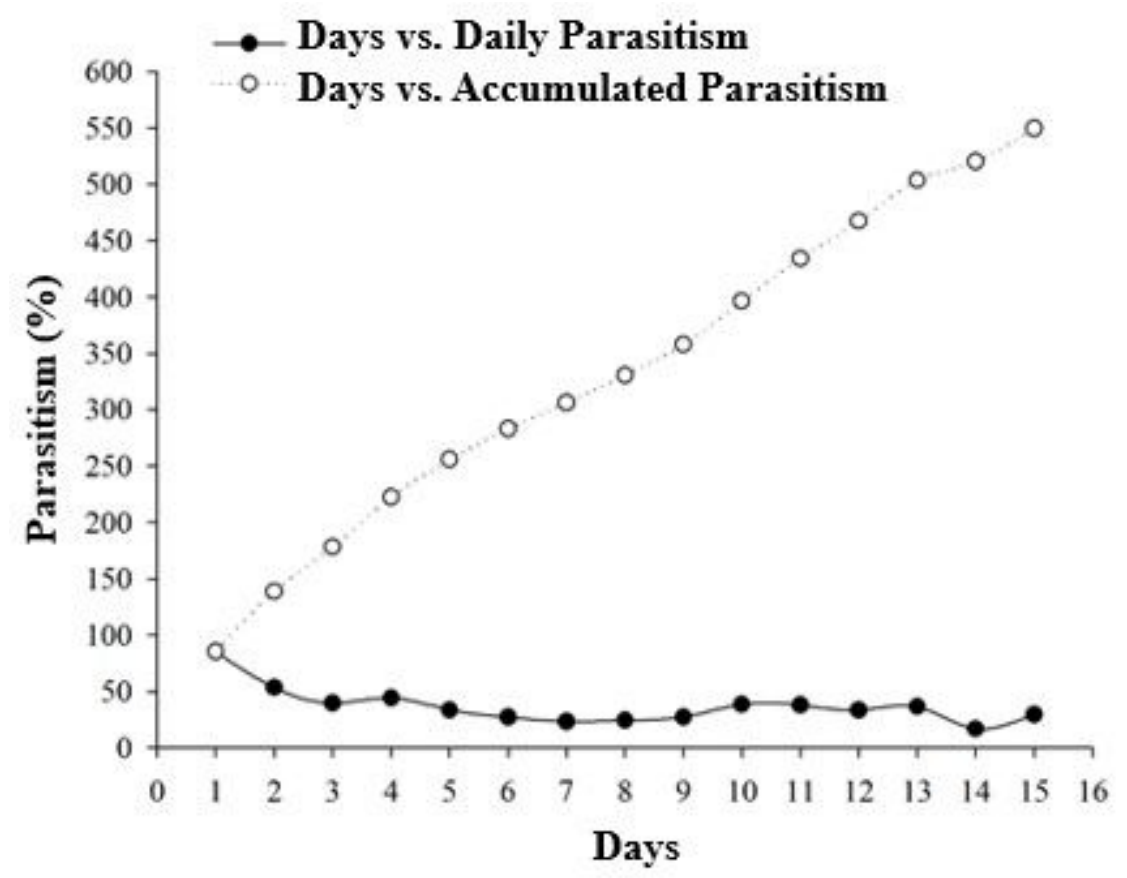

Figure 1

Average daily and accumulated number of parasitized eggs of Corcyra cephalonica by Trichogramma pretiosum.

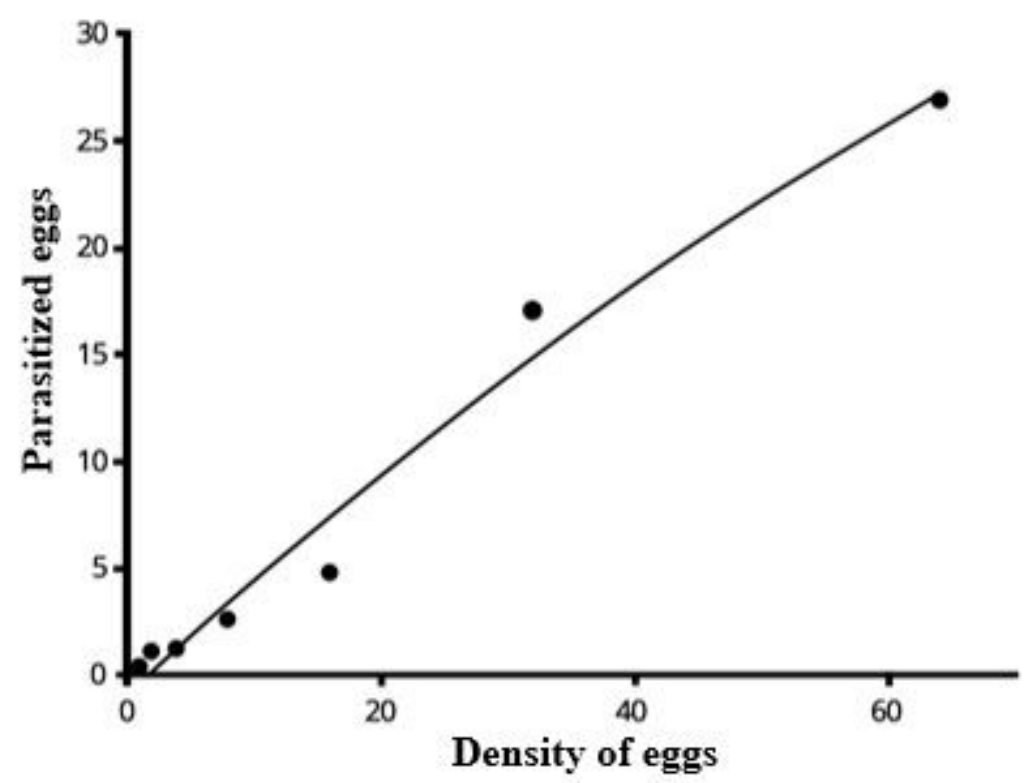

Figure 2

Average number of Corcyra cephalonica eggs, in different densities, parasitized by Trichogramma pretiosum, in $24 \mathrm{~h}$ of exposure. 